\title{
Effector Protease Receptor 1 Mediates the Mitogenic Activity of Factor Xa for Vascular Smooth Muscle Cells In Vitro and In Vivo
}

\author{
J.-M. Herbert, F. Bono, J.-P. Hérault, C. Avril, F. Dol, A.-M. Mares, and P. Schaeffer \\ Haemobiology Research Department, Sanofi Recherche, 31036 Toulouse, France
}

\begin{abstract}
The binding of ${ }^{125} \mathrm{I}-$ factor Xa to human aortic smooth muscle cell (SMC) monolayers was studied. At $4{ }^{\circ} \mathrm{C},{ }^{125} \mathrm{I}-$ factor $\mathrm{Xa}$ bound to a single class of binding sites with a dissociation constant value of $3.6 \pm 0.7 \mathrm{nM}$ and a binding site density of 11,720 $\pm 1,240$ sites/cell $(n=9) .{ }^{125}$ I-factor Xa binding was not affected by factor $\mathrm{X}$, thrombin, or by DX9065, a direct inhibitor of factor $\mathrm{Xa}$, but was inhibited by factor $\mathrm{Xa}$ $\left(\mathrm{IC}_{50}=5.4 \pm 0.2 \mathrm{nM} ; n=9\right)$ and by antibodies specific for the effector cell protease receptor 1 (EPR-1), a well-known receptor of factor $\mathrm{Xa}$ on various cell types. A factor $\mathrm{X}$ peptide duplicating the inter-EGF sequence $\mathrm{Leu}^{83}-\mathrm{Leu}^{88}$-(Gly) blocked the binding of ${ }^{125} \mathrm{I}$-factor $\mathrm{Xa}$ to these cells in a dose-dependent manner $\left(\mathrm{IC}_{50}=110 \pm 21 \mathrm{nM}\right)$. Factor Xa increased phosphoinositide turnover in SMCs and when added to SMCs in culture was a potent mitogen. These effects were inhibited by DX9065 and by antibodies directed against EPR-1 and PDGF. Increased expression of EPR-1 was identified immunohistochemically on SMCs growing in culture and in SMCs from the rabbit carotid artery after vascular injury. When applied locally to air-injured rabbit carotid arteries, antibodies directed against EPR-1 (100 $\mu \mathrm{g} /$ artery) strongly reduced myointimal proliferation $14 \mathrm{~d}$ after vascular injury $(65-71 \%$ inhibition, $P<0.01)$. DX9065 (10 $\mathrm{mg} / \mathrm{kg}$, subcutaneous) inhibited myointimal proliferation significantly ( $43 \%$ inhibition, $P<0.05$ ). These findings indicate that SMCs express functional high affinity receptors for factor Xa related to EPR-1, which may be of importance in the regulation of homeostasis of the vascular wall and after vascular injury. (J. Clin. Invest. 1998. 101:993-1000.) Key words: smooth muscle cells • factor Xa • effector cell protease receptor $1 \cdot$ myointimal $\bullet$ restenosis
\end{abstract}

\section{Introduction}

Arterial injury is known to activate the coagulation cascade through the intrinsic and extrinsic pathways with the generation of factor Xa. Factor Xa in combination with the nonenzymatic cofactor $\mathrm{Va}$ and calcium assembles into a prothrombinase complex on the surface membrane of activated platelets

Address correspondence to J.M. Herbert, Haemobiology Research Department, Sanofi Recherche, 195 Route d'Espagne, 31036 Toulouse, France. Phone: 33-05-61-16-23-61; FAX: 33-05-61-16-22-86; E-mail: jean-marc.herbert@tls1.elfsanofi.fr

Received for publication 25 September 1997 and accepted in revised form 18 December 1997.

J. Clin. Invest.

(C) The American Society for Clinical Investigation, Inc. 0021-9738/98/03/0993/08 \$2.00

Volume 101, Number 5, March 1998, 993-1000

http://www.jci.org and catalyzes the conversion of prothrombin to thrombin. In addition to its important role in the coagulation cascade, factor $\mathrm{Xa}$ has been shown to stimulate smooth muscle cell (SMC) proliferation in vitro (1), causing the release of PDGF and leading eventually to DNA synthesis and cell proliferation (2). Moreover, it has been demonstrated that specific inhibition of factor $\mathrm{Xa}$ by recombinant antistasin and tick anticoagulant peptide reduced factor $\mathrm{Xa}$-induced SMC proliferation in vitro (1) and in vivo after balloon angioplasty in a rabbit model of femoral atherosclerosis (3).

Considerable interest has been focused on the identification and characterization of binding sites for factor Xa on vascular cells. In particular, it has been shown recently that a membrane protein similar to the light chain of factor Va was the membrane receptor of factor Xa on monocyte (4). This protein, called effector cell protease receptor 1 (EPR-1), which was also detected on endothelial cells $(5,6)$, behaved as a cofactor for factor $\mathrm{Xa}$ to catalyze prothrombin activation in the absence of added factor $\mathrm{Va}(5,6)$.

In a recent work, ${ }^{2}$ we showed that when added to cultured human umbilical vein endothelial cells (HUVECs), factor Xa not only bound to EPR-1 but also increased intracellular free calcium, phosphoinositide turnover, tissue factor expression, and release of tissue-type plasminogen activator, plasminogen activator inhibitor 1 , and proliferation. These effects were dependent on the catalytic activity of factor $\mathrm{Xa}$ and could be inhibited by both direct (DX9065) (7) and indirect (antithrombin/pentasaccharide) (8) factor Xa inhibitors. Moreover, by analogy with the paradigm of thrombin, we found recently that factor $\mathrm{Xa}$ at low concentrations was able to induce endothelium-dependent relaxation of rat aortic rings (9). These effects of factor Xa which occurred via EPR-1 required factor Xa to be catalytically active. Collectively, the results of these experiments strongly suggest that factor Xa might act as a mitogen on SMCs via specific cell surface receptors. In that respect, Nicholson et al. suggested that EPR-1 might be the receptor responsible for the mitogenic activity of factor Xa with regard to both HUVECs and SMCs (5).

The aim of this study was to characterize the interaction between factor $\mathrm{Xa}$ and aortic SMCs and to further elucidate the functional consequences of factor $\mathrm{Xa}$ binding on these cells. Since recent studies have also underscored the participation of protease receptors in the pleiotropic mechanisms of vascular cell signal transduction, including transcription of activation-dependent genes and generation of intracellular second messengers, we also determined the effect of factor Xa on phosphoinositide turnover and proliferation of SMCs in vitro and in vivo after injury of the rabbit carotid artery.

1. Abbreviations used in this paper: $\mathrm{b}$, basic; EPR-1, effector cell protease receptor 1; HUVEC, human umbilical vein endothelial cell; SMC, smooth muscle cell.

2. Hérault, J.-P., F. Bono, C. Avril, P. Schaeffer, and J.M. Herbert, manuscript submitted for publication. 


\section{Methods}

\section{Materials}

Human ${ }^{125} \mathrm{I}$-factor $\mathrm{Xa}$ (specific activity $2,000 \mathrm{Ci} / \mathrm{mmol}$ ) and myo- ${ }^{3} \mathrm{H}-$ inositol $(100 \mathrm{Ci} / \mathrm{mmol})$ were from Amersham International (Little Chalfont, Bucks, UK). Factor Xa and factor X from human plasma were purchased from Enzyme Research Laboratories (Swansea, UK). Human $\alpha$-thrombin $(3,000 \mathrm{IU} / \mathrm{mg})$ was from Centre de Transfusion Sanguine (Strasbourg, France). The inter-EGF sequence $\mathrm{L}^{83} \mathrm{FTRKL}^{88}(\mathrm{G})$ and its control scrambled variant $\mathrm{K}^{83} \mathrm{FTGRLL}^{88}$ were synthetized by Neosystem (Strasbourg, France). Recombinant hirudin (rHv2-Lys 47 variant) was from Sanofi Recherche (Toulouse, France). DX9065 was from Daichi Pharmaceuticals Co. Ltd. (Tokyo, Japan). mAbs directed against human basic FGF (bFGF), and platelet-derived growth factor (PDGF-BB) were from R \& D Systems (Abingdon, UK). Antibodies to EPR-1 (B6 and 12H1) or to the interEGF domain of factor Xa (JC15) were as described $(4,10)$. FCS and tissue culture reagents were from Boehringer Mannheim France S.A. (Meylan, France). Human aortic SMCs were from Clonetics Corp. (Tebu, Le Perray, France).

\section{Cell culture}

SMCs were routinely cultured in $75-\mathrm{cm}^{2}$ flasks in DME containing $10 \%$ FCS, $100 \mathrm{IU}$ penicillin, $100 \mu \mathrm{g} / \mathrm{ml}$ streptomycin, and $2 \mathrm{mM}$ glutamine. For experiments, cells were detached by trypsin/EDTA $(0.05-0.02 \%)$, seeded in 24 -well plates, and used at confluence. Cells were used between the third and tenth passages without noticeable modifications of the tested parameters.

\section{Binding experiments}

${ }^{125}$ I-factor Xa binding experiments were performed on cell monolayers $\left(3 \times 10^{5}\right.$ cells/well $)$. Medium was aspirated, and cells were washed twice with buffer containing $137 \mathrm{mM} \mathrm{NaCl}, 4 \mathrm{mM} \mathrm{KCl}, 11 \mathrm{mM}$ glucose, $10 \mathrm{mM}$ EDTA, Hepes $10 \mathrm{mM}$, pH 7.45. SMCs were then incubated at $4{ }^{\circ} \mathrm{C}$ with $200 \mu$ l of the same buffer without EDTA, containing $0.5 \% \mathrm{BSA}$ and $5 \mathrm{mM} \mathrm{CaCl}_{2}$ in the presence of ${ }^{125} \mathrm{I}$-factor $\mathrm{Xa}(1 \mathrm{nM})$ and the tested compounds. At the end of the incubation period, the buffer was aspirated, and the cells were washed three times with icecold binding buffer. Cells were then digested with $1 \mathrm{ml} \mathrm{NaOH} 0.2 \mathrm{~N}$, SDS $1 \%$, EDTA $10 \mathrm{mM}$ for $5 \mathrm{~min}$, and the resulting solution was counted in a gamma counter. Results for equilibrium binding experiments, kinetic experiments, and binding inhibition studies were analyzed (11).

\section{Measurement of phosphoinositide turnover}

Confluent cell monolayers in 60-mm dishes were incubated for $72 \mathrm{~h}$ in normal culture medium containing $5 \mu \mathrm{Ci} / \mathrm{ml}$ of myo- ${ }^{3} \mathrm{H}$-inositol. Medium was then aspirated, and the cell monolayers were washed twice with PBS and incubated for 30 min with PBS containing $20 \mathrm{mM}$ of $\mathrm{LiCl}$. Cells were then stimulated in the same medium with different concentrations of factor $\mathrm{Xa}$ for an additional $30 \mathrm{~min}$ at $37^{\circ} \mathrm{C}$. At the end of the incubation period, buffer was aspirated, and the cells were extracted with an ice-cold methanol/HCl $0.1 \mathrm{~N} \mathrm{(50:50)} \mathrm{solution} \mathrm{for} 30$ min. Extracts were then neutralized with $1 \mathrm{M} \mathrm{Na}_{2} \mathrm{CO}_{3}$, and $\left[{ }^{3} \mathrm{H}\right]$ inositol monophosphate was separated as described by Berridge et al. (12) using columns containing $1 \mathrm{ml}$ of AG1-X8 resin.

\section{Culture and proliferation assays of SMCs}

Cells were plated sparsely $\left(10^{4}\right.$ cells/well $)$ in 24 -well cluster plates in DME plus $0.5 \%$ FCS. After $3 \mathrm{~d}$ in culture, the medium was removed, and fresh DME was supplemented with $0.5 \%$ FCS and factor Xa. After $3 \mathrm{~d}$ in culture, cells were detached from triplicate wells by trypsin treatment $(0.05 \%$ trypsin $/ 0.02 \%$ EDTA $)$ and counted in a cell counter.

\section{In vivo experiments}

Air-drying injury. Male New Zealand rabbits (Lago, Vonnas, France) weighing $2.5-3 \mathrm{~kg}$ were used. Air-drying injury was induced by applying an air flow through the carotid artery using a modification of Fish- man's method (13). Rabbits were anesthetized by intravenous (i.v.) injection of a mixture of acepromazine $\left(0.3 \mathrm{mg} / \mathrm{kg}\right.$, Vetranquil ${ }^{\circledR}$; Sanofi Winthrop, Gentilly, France) and ketamine $(15 \mathrm{mg} / \mathrm{kg}$, Imalgene 1000; Rhône Merieux, Lyon, France). The left carotid artery was exposed and ligatured at two points $1.5 \mathrm{~cm}$ apart. A 27-gauge hypodermic needle was inserted into the proximal end of the segment by puncturing with an additional needle. After the lumen had been rinsed with saline, a stream of dry air was allowed to flow through the segment at $240 \mathrm{ml} / \mathrm{min}$ for $5 \mathrm{~min}$. After air-drying injury, ligatures were removed, allowing circulation to be reestablished, and hemostasis was ensured. Antibodies were dissolved in a 20\% (wt/vol) F127 pluronic gel solution (BASF; Wyandotte Corp., Wyandotte, MI) at a concentration of $1 \mathrm{mg} / \mathrm{ml} .100 \mu \mathrm{l}$ of the gel solution containing the antibody was applied to surround the exposed region of the carotid artery, and the incision was closed. The right carotid artery was manipulated but not submitted to air-drying injury to serve as control. In DX9065-treated animals, the drug was administered by subcutaneous (s.c.) route $(10 \mathrm{mg} / \mathrm{kg} / \mathrm{d}) 5 \mathrm{~min}$ after the injury and twice daily for $14 \mathrm{~d}$.

Tissue preparation and morphologic examination. $14 \mathrm{~d}$ after surgery, animals were anesthetized with sodium pentobarbitone $(30 \mathrm{mg}$ / $\mathrm{kg}$, i.v.). The carotid artery was perfusion-fixed (1\% paraformaldehyde), isolated, rinsed with saline, and fixed overnight with a $10 \%$ formaldehyde solution. The arterial segments were then dehydrated through graded solutions of alcohol, embedded in paraffin for serial cross sectioning, and stained with hematoxylin-eosin. Maximal plaque size was used as an indicator of SMC proliferation. For that purpose, 50 cross sections disposed throughout the length of the injured vessel were examined, and the maximum proliferation was determined quantitatively. Morphometric analysis of arterial sections presenting a maximum of proliferation was done with an image analysis system (Imagenia 2000; Biocom, Lyon, France).

Immunohistochemical detection of EPR-1. EPR-1 immunohistochemistry was performed on serial frozen sections of rabbit carotid arteries which were postfixed with $4 \%$ formaldehyde. Frozen tissue sections were reacted with an anti-EPR-1 mAb (12H1) prepared as described previously (4). Primary antibody was detected by indirect immunohistochemistry with a peroxidase-conjugated anti-IgM $\mathrm{mAb}$ (Sigma Chemical Co., St. Louis, MO). Staining was visualized by using diaminobenzidine tetrahydrochloride and $\mathrm{H}_{2} \mathrm{O}_{2}$ as substrates.

\section{Western analysis of EPR-1}

EPR-1 expression was determined according to Nicholson et al. (5). SMCs in culture (cultured for $24 \mathrm{~h}$ in 0.5 or $10 \%$ FCS) or from rabbit carotid arteries (normal or $14 \mathrm{~d}$ after air injury) were washed with PBS and homogenized in lysis buffer (1\% Triton, 0.1\% P-40, $20 \mathrm{mM}$ Tris, $\mathrm{pH} 7.4,150 \mathrm{mM} \mathrm{NaCl}, 20 \mu \mathrm{g} / \mathrm{ml}$ aprotinin, $10 \mu \mathrm{g} / \mathrm{ml}$ soybean trypsin inhibitor, $2 \mathrm{mM}$ PMSF, $10 \mathrm{mM}$ benzamidine). Lysis continued at $4^{\circ} \mathrm{C}$ for $30 \mathrm{~min}$, after which the lysate was clarified by centrifugation, and the protein concentration was determined. $5 \times$ sample buffer was diluted to $1 \times$; samples were run on $7 \%$ SDS-PAGE gels applying $500 \mu \mathrm{g}$ of protein/lane. The protein bands were transferred to Immobilon-P, and EPR-1 protein was detected using the enhanced chemiluminescence protocol (Amersham International) with the anti-EPR-1 mAb $12 \mathrm{H} 1$ at $10 \mu \mathrm{g} / \mathrm{ml}$.

\section{Statistical analysis of data}

All data are expressed as mean \pm SD. The $n$ values indicate the number of data points. Grouped data were analyzed for significance by comparison with the vehicle-treated group using the Mann-Whitney $\mathrm{U}$ test. The level of significance was chosen as $P<0.05$.

\section{Results}

The kinetics of ${ }^{125} \mathrm{I}$-factor Xa binding to human SMCs indicated that the association of ${ }^{125} \mathrm{I}$-factor $\mathrm{Xa}(1 \mathrm{nM})$ at $4^{\circ} \mathrm{C}$ was nearly complete after $1 \mathrm{~h}$ of incubation and remained stable for up to $4 \mathrm{~h}$ (Fig. 1). Binding studies carried out at $37^{\circ} \mathrm{C}$ gave results which were identical to those from experiments per- 


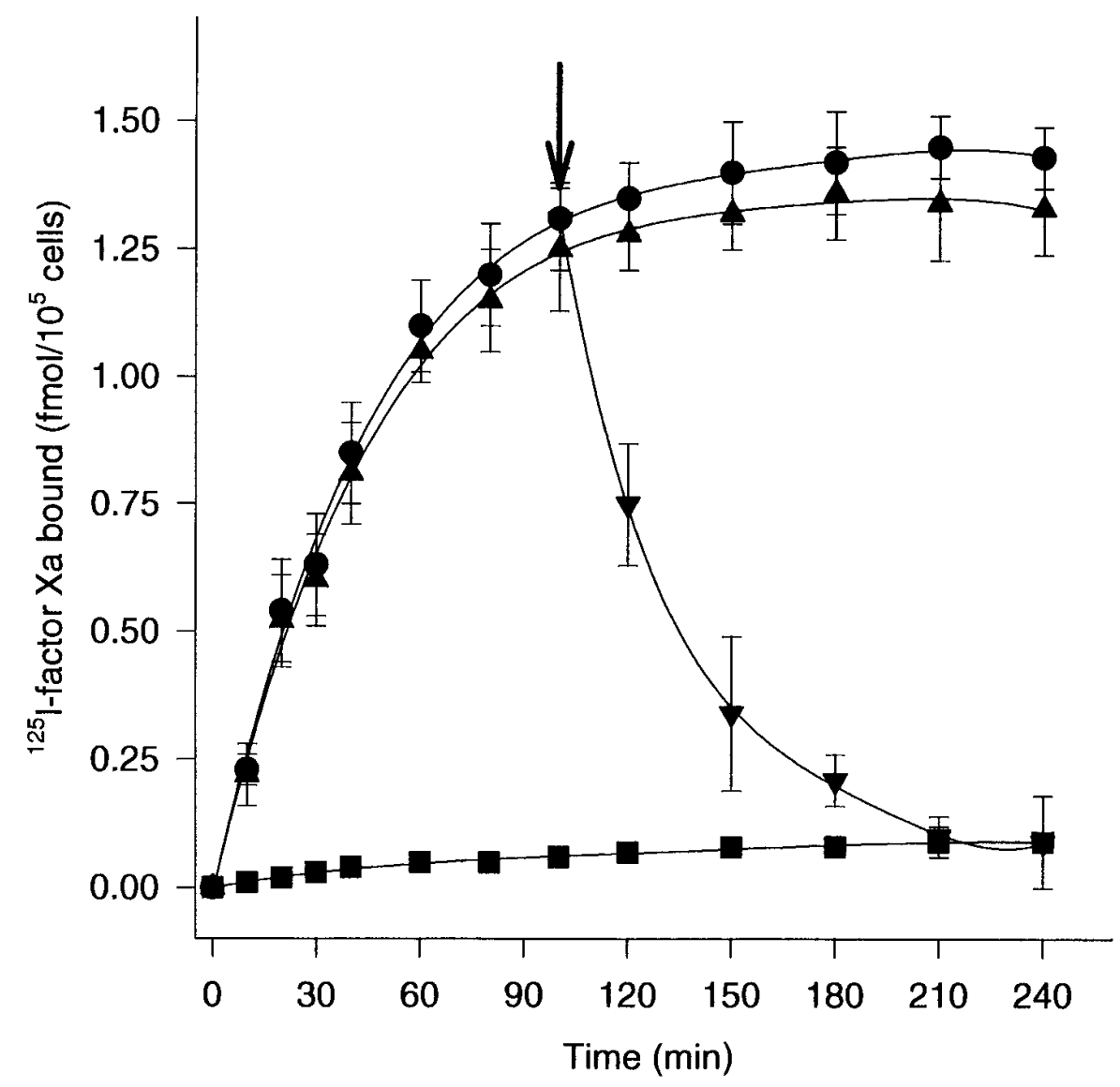

Figure 1. Time course of ${ }^{125} \mathrm{I}$-factor Xa binding to aortic human SMCs. Confluent cells $\left(3 \times 10^{5}\right.$ cells/well) were incubated at $4^{\circ} \mathrm{C}$ with ${ }^{125} \mathrm{I}$-factor Xa $(1 \mathrm{nM})$. Nonspecific binding ( $\mathbf{\square})$ was determined in the presence of $1 \mu \mathrm{M}$ unlabeled factor Xa and was subtracted from total binding $(\bullet)$ to give specific binding $(\boldsymbol{\Delta})$ at each time point. $A r$ row, Time at which the dissociation process was started by adding unlabeled factor Xa $(1 \mu \mathrm{M})(\boldsymbol{\nabla})$. Data are mean \pm SD of three experiments performed in triplicate. formed at $4^{\circ} \mathrm{C}$ (not shown). Therefore, further experiments were carried out at $4^{\circ} \mathrm{C}$ in order to study binding, while minimizing degradation of factor $\mathrm{Xa}$ which is likely to occur at $37^{\circ} \mathrm{C}$. As shown in Fig. 1, the mean data were well described by a monoexponential equation corresponding to a pseudo-first order association reaction, with $k_{\mathrm{obs}}=38.4 \pm 6.1 \mathrm{~min}^{-1}\left(t_{1 / 2}=\right.$ $27.2 \mathrm{~min}$ ). Dissociation of ${ }^{125} \mathrm{I}$-factor Xa could be induced by unlabeled factor Xa (Fig. 1). Dissociation was rapid, with a half-life of $34 \mathrm{~min}$, corresponding to a dissociation rate constant $\left(k_{-1}\right)$ of $3.1 \times 10^{-4} \mathrm{~s}^{-1}$. A small percentage of ${ }^{125} \mathrm{I}$-factor $\mathrm{Xa}(5.4 \%)$ did not dissociate and remained associated to the cells even after $2 \mathrm{~h}$ of incubation. The association rate constant $k_{+1}$ was found to be $0.17 \times 10^{6} \mathrm{M}^{-1} \mathrm{~s}^{-1}$. Calculating the dissociation constant $K_{\mathrm{d}}=\mathrm{k}_{-1} / \mathrm{k}_{+1}$ gave a value of $3.1 \mathrm{nM}$. The binding of ${ }^{125} \mathrm{I}$-factor Xa to SMCs was calcium dependent, with a concentration of $10 \mathrm{mM}$ of $\mathrm{CaCl}_{2}$ necessary for optimal binding (not shown).

As shown in Fig. 2, ${ }^{125} \mathrm{I}$-factor Xa binding to SMC monolayers at $4{ }^{\circ} \mathrm{C}$ was saturable, with a nonspecific binding representing $<10 \%$ of total binding at saturation. The Scatchard plot (Fig. $2 \mathrm{~B}$, inset) was linear, indicative of a single class of noninteracting binding sites. From several experiments, the mean dissociation constant value $\left(K_{\mathrm{d}}\right)$ was found to be 3.6 \pm $0.7 \mathrm{nM}$, and the binding site density $\left(B_{\max }\right)$ represented $11,720 \pm 1,240$ sites/cell $(n=9)$. Factor Xa inhibited ${ }^{125}$ I-factor $\mathrm{Xa}$ binding in a monophasic manner, with the slope factor close to one. The $\mathrm{IC}_{50}$ value (concentration which inhibited $50 \%$ of the specific binding of ${ }^{125} \mathrm{I}$-factor Xa) was $5.4 \pm 0.2 \mathrm{nM}$ $(n=9)$. Binding constants $\left(K_{\mathrm{d}}\right.$ and $\left.B_{\max }\right)$ calculated from this competition experiment ( $6.4 \mathrm{nM}$ and 14,270 sites/cell, respectively) were close to the affinity constants determined from saturation experiments. When tested in the same experimental conditions, factor $\mathrm{X}$ did not affect the binding of ${ }^{125} \mathrm{I}$-factor $\mathrm{Xa}$ to SMCs. The effect of a direct factor Xa inhibitor (DX9065), enzymes, and antibodies on ${ }^{125} \mathrm{I}$-factor Xa binding to SMCs was evaluated, but among the various compounds tested, none affected the specific binding of ${ }^{125} \mathrm{I}$-factor Xa except the mAbs

Table I. Effect of Various Compounds on the Specific Binding of ${ }^{125}$ I-Factor Xa to Human SMCs

\begin{tabular}{|c|c|c|}
\hline Compounds & Dose & Percent inhibition \\
\hline & & $\%$ \\
\hline Factor Xa & $100 \mathrm{nM}$ & $100\left(\mathrm{IC}_{50}=5.4 \pm 0.2 \mathrm{nM}\right)$ \\
\hline Factor $\mathrm{X}$ & $1 \mu \mathrm{M}$ & 9 \\
\hline Thrombin & $290 \mathrm{nM}$ & 7 \\
\hline Anti-EPR-1 (B6) & $50 \mu \mathrm{g} / \mathrm{ml}$ & 98 \\
\hline Anti-EPR-1 (12H1) & $50 \mu \mathrm{g} / \mathrm{ml}$ & 100 \\
\hline Anti-factor Xa (JC15) & $50 \mu \mathrm{g} / \mathrm{ml}$ & 97 \\
\hline Anti-IgG & $50 \mu \mathrm{g} / \mathrm{ml}$ & 2 \\
\hline $\mathrm{L}^{83} \mathrm{FTRKLL}^{88}(\mathrm{G})$ & $300 \mu \mathrm{g} / \mathrm{ml}$ & $87\left(\mathrm{IC}_{50}=110 \pm 21 \mathrm{nM}\right)$ \\
\hline KFTGRLL & $300 \mu \mathrm{g} / \mathrm{ml}$ & 5 \\
\hline Hirudin & $50 \mathrm{nM}$ & 1 \\
\hline DX9065 & $10 \mu \mathrm{M}$ & 5 \\
\hline
\end{tabular}

Values are means $\pm \operatorname{SD}(n=9)$. 


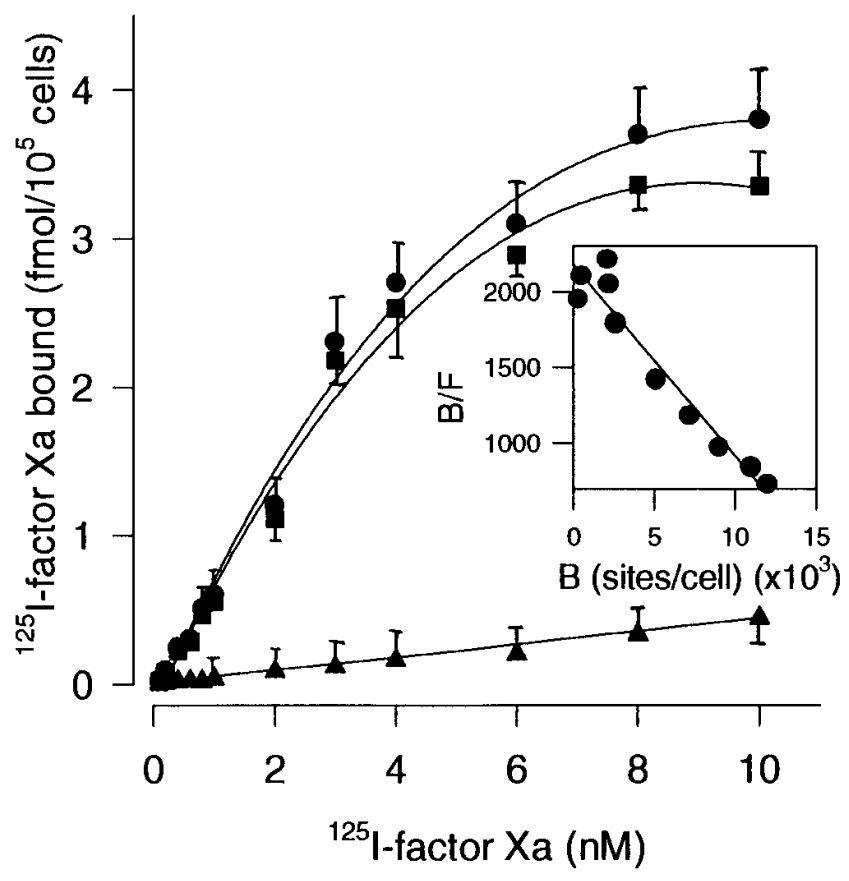

Figure 2. ${ }^{125} \mathrm{I}$-factor Xa binding to human SMC monolayers. Confluent cells $\left(3 \times 10^{5}\right.$ cells/well $)$ were incubated for $100 \mathrm{~min}$ at $4^{\circ} \mathrm{C}$ with increasing concentrations of ${ }^{125} \mathrm{I}$-factor $\mathrm{Xa}$ in the presence or absence of $1 \mu \mathrm{M}$ unlabeled factor Xa. Total $(\bullet)$ and nonspecific binding $(\mathbf{\Delta})$ were determined as described in Methods. The specific binding of ${ }^{125} \mathrm{I}$-factor Xa ( $\left.\mathbf{\square}\right)$ was determined as the difference between total and nonspecific binding. (Inset) Scatchard plot of the specific binding of ${ }^{125} \mathrm{I}$-factor Xa calculated from saturation isotherms determined from at least three independent experiments performed in triplicate. Means \pm SD.

B6 and 12H1 (directed against EPR-1), which strongly affected the binding of ${ }^{125}$ I-factor Xa to SMCs (Table I). Binding of ${ }^{125} \mathrm{I}$-factor Xa to SMCs was also inhibited in a dose-dependent manner by the inter-EGF factor $\mathrm{X}$ peptide sequence $\mathrm{Leu}^{83}-\mathrm{Leu}^{88}$ or by an antibody directed against it (JC15), but not by the $\mathrm{Lys}^{83}{ }^{-\mathrm{Leu}^{88}}$ control scrambled peptide or by a control anti-IgG. When determined at $37^{\circ} \mathrm{C}$, similar results were obtained (not shown).

Effect of factor Xa on phosphoinositide turnover. As shown in Fig. 3, factor Xa increased phosphoinositide turnover in human SMCs in a concentration-dependent manner, with an $\mathrm{ED}_{50}$ value of $68.2 \pm 4.1 \mathrm{nM}(n=9)$, whereas under the same experimental conditions, factor $X$ at concentrations up to $1 \mu \mathrm{M}$ did not show any effect. DX9065 and B6, an anti-EPR-1 antibody, inhibited in a dose-dependent manner factor $\mathrm{Xa}$-induced $(100 \mathrm{nM})$ phosphoinositide turnover in SMCs. The $\mathrm{IC}_{50}$ values were found to be $10.8 \pm 0.7 \mathrm{nM}$ and $12 \pm 4 \mu \mathrm{g} / \mathrm{ml}$ for DX9065 and B6, respectively (Fig. 3, inset).

Effect of factor Xa on the proliferation of SMCs in culture. Factor Xa stimulated in a dose-dependent manner the growth of human SMCs in vitro (Fig. 4). The concentration of factor Xa required to obtain optimal cell proliferation $\left(A_{\max }\right)$ was between 80 and $100 \mathrm{nM}$, with a half-maximal response $\left(\mathrm{ED}_{50}\right)$ at $10.4 \mathrm{nM}$. A similar effect was observed with rabbit SMCs (Table II). At the $A_{\max }$, the doubling time of the SMCs was $\sim 24 \mathrm{~h}$. At the highest dose, this effect represented $70-80 \%$ of the mitogenic effect of $5 \%$ FCS. Under the same experimental condi-
Table II. Effect of Various Antibodies $(50 \mu \mathrm{g} / \mathrm{ml})$ on Factor Xa (100 nM)-induced Human and Rabbit SMC Growth

\begin{tabular}{llc}
\hline & \multicolumn{1}{c}{$\begin{array}{c}\text { Human } \\
\text { SMCs/well }\end{array}$} & $\begin{array}{c}\text { Rabbit } \\
\text { SMCs/well }\end{array}$ \\
\hline $0.5 \%$ FCS & $18200 \pm 410$ & $12200 \pm 110$ \\
Factor Xa & $85400 \pm 470$ & $74800 \pm 510$ \\
Factor Xa + mAb anti-bFGF & $86200 \pm 1210$ & $75600 \pm 820$ \\
Factor Xa + mAb anti-PDGF-BB & $28800 \pm 220$ & $21100 \pm 270$ \\
Factor Xa + mAb B6 & $42030 \pm 190$ & $72700 \pm 430$ \\
Factor Xa + mAb 12H1 & $21200 \pm 560$ & $14600 \pm 270$ \\
Factor Xa + mAb JC15 & $24600 \pm 430$ & $26100 \pm 150$ \\
\hline
\end{tabular}

Values are means \pm SD $(n=9)$.

tions, factor $\mathrm{X}$ did not show any mitogenic effect (not shown). Moreover, hirudin $(50 \mathrm{nM})$ did not show any significant effect on factor $\mathrm{Xa}$-induced SMC proliferation ( $2 \%$ inhibition, $P>$ $0.05)$. This shows that the effect observed is a direct effect of factor Xa and is not due to thrombin formation that might occur during the incubation period. When tested under the same experimental conditions, thrombin exhibited a similar mitogenic effect (Fig. 4). The mitogenic activity of factor Xa was dependent on the catalytic activity of the enzyme as demonstrated by the inhibitory effect of DX9065 $\left(\mathrm{IC}_{50}=9.6 \pm 1.2\right.$ $\mathrm{nM}$ ), which dose-dependently inhibited factor Xa-induced proliferation of SMCs (Fig. 4, inset). To determine if such a mitogenic effect of factor Xa for human and rabbit SMCs was due to the release of growth factors by the cells, we evaluated the activity of neutralizing $\mathrm{mABs}$ directed against $\mathrm{bFGF}$ and PDGF (BB dimer). From the antibodies tested, only the antibody directed against PDGF-BB inhibited factor $\mathrm{Xa}$-induced SMC growth (Table II). Under these experimental conditions, antibodies directed against EPR-1 $(50 \mu \mathrm{g} / \mathrm{ml})$ inhibited the proliferation of human SMCs induced by $100 \mathrm{nM}$ of factor Xa (Table II). However, with regard to rabbit SMCs, only $12 \mathrm{H} 1$ and JC15 reduced factor Xa-induced SMC proliferation, with B6 inactive in this species (Table II).

Expression of EPR-1 in SMCs in vitro and in vivo. To determine whether human SMCs can synthesize and express EPR-1, we analyzed protein levels for EPR-1 by Western blots (Fig. 5). In agreement with previous observations (5), Western blot analysis demonstrated an $\sim 65 \mathrm{kD}$ protein present in arterial SMC lysate of both cultured quiescent SMCs and in the rabbit carotid artery (Fig. 5, $A$ and $C$ ). Increased expression of EPR-1 protein levels was observed in SMCs cultured for $24 \mathrm{~h}$ in $10 \%$ FCS, or $14 \mathrm{~d}$ after vascular injury of the rabbit carotid artery (Fig. 5, $B$ and $D$ ).

To further substantiate the functional expression of EPR-1 by the vascular cells in vivo, immunohistochemical analysis for EPR-1 was carried out (Fig. 6). The anti-EPR-1 antibody $12 \mathrm{H} 1$ reacted strongly with sections of rabbit carotid arteries (Fig. 6 A). Endothelial cells and some adventitial cells were immunoreactive, whereas a low level of staining could be observed in SMCs present in the media. Consistent with the results obtained by Western blotting (Fig. $5 \mathrm{D}$ ), the expression of EPR-1 protein in the rabbit carotid artery was increased $14 \mathrm{~d}$ after endothelial injury, and EPR-1-containing cells were found distributed diffusely throughout the neointima and the media (Fig. $6 B$ ). 


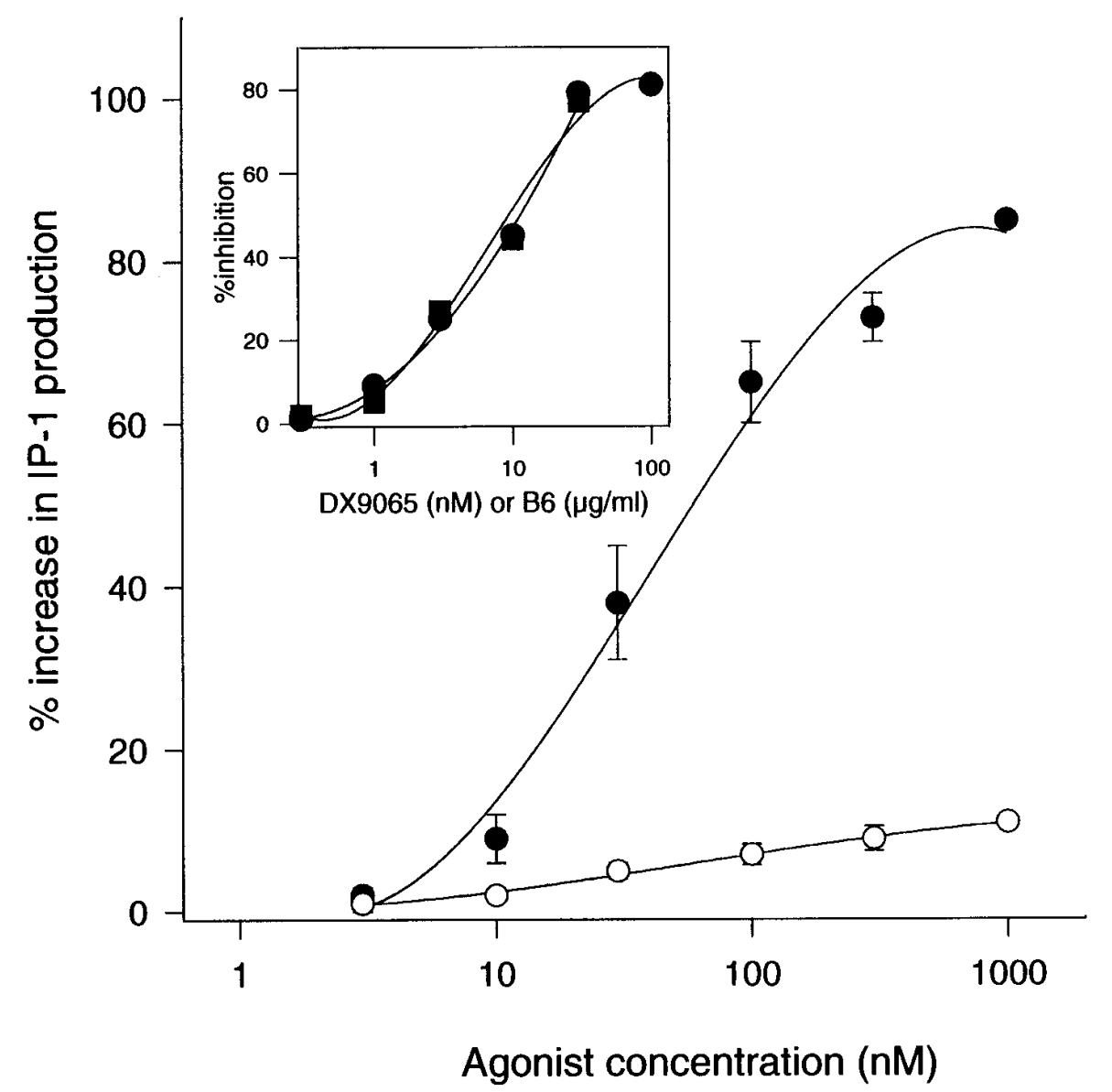

Figure 3. Effect of factor Xa on phosphoinositide metabolism in human SMCs. Cell monolayers were incubated for $30 \mathrm{~min}$ with different concentrations of factor $\mathrm{Xa}(\bullet)$ or factor $\mathrm{X}(\mathrm{O})$, and inositol monophosphate accumulation was determined as described in Methods. (Inset) Effect of DX9065 (•) and B6 (ם) on factor Xa (100 nM)-induced phosphoinositide turnover. Results are expressed as percent increase of the control value, and are the mean $\pm \mathrm{SD}$ of four determinations performed in triplicate.
Effect of anti-EPR-1 antibodies and DX9065 on the myointimal proliferation after air-drying injury of the rabbit carotid artery. Because an anti-EPR-1 antibody (12H1) and JC15 (a polyclonal antibody against the inter-EGF sequence of factor $\mathrm{Xa}$ ) inhibited factor Xa-induced rabbit SMC growth (Table II), we sought to determine whether the local application of these antibodies modified vessel wall response to injury. We also determined the effect of DX9065 (10 mg/kg, s.c.), which also inhibited the mitogenic activity of factor Xa. Computerized morphometry was carried out on the carotid artery section, demonstrating the largest neointimal lesion as identified by histopathological analysis. In the right carotid artery (which had not been subjected to air injury), there was no evidence of intimal proliferation or foam cell or platelet accumulation $14 \mathrm{~d}$ after the surgical procedure, indicating that physical manipulation at the time of surgery but without air-drying injury was not sufficient to generate the lesion. However, 2 wk after endothelial injury of the left rabbit carotid artery, the intima had grown substantially and represented $37.9 \pm 3.9 \%$ of the tunica media area. Medial and neointimal areas in the control group $14 \mathrm{~d}$ after endothelial injury were $0.29 \pm 0.04$ and $0.11 \pm 0.02$ $\mathrm{mm}^{2}$, respectively $(n=12)$. Morphometric analysis revealed that changes in the increase in the intimal diameter occurred while the medial diameter remained mostly unchanged (Table III). The neointima extended to the entire circumference and $\sim 80 \%$ of the length of the injured area. No differences in morphometric parameters in the controls receiving either saline or the F-127 pluronic gel solution were noted (data not shown).

As shown in Table III, topical application of the anti-EPR-1 antibodies $12 \mathrm{H} 1$ and $\mathrm{JC} 15(100 \mu \mathrm{g} /$ artery $)$ affected significantly SMC hyperplasia after deendothelialization $(65 \pm 5$ and

Table III. Effect of 12H1, JC15, and DX9065 on Myointimal Proliferation after Vascular Injury of the Rabbit Carotid Artery

\begin{tabular}{|c|c|c|c|c|c|c|}
\hline Compounds & Dose & Intima & Media & Intima/media & Percent inhibition & $P^{*}$ \\
\hline & & & & & $\%$ & \\
\hline Saline & - & $0.11 \pm 0.02$ & $0.29 \pm 0.04$ & 0.38 & - & - \\
\hline $12 \mathrm{H} 1$ & $100 \mu \mathrm{g} /$ artery & $0.03 \pm 0.01$ & $0.25 \pm 0.06$ & 0.13 & $65 \pm 5$ & $<0.01$ \\
\hline $\mathrm{JC} 15$ & $100 \mu \mathrm{g} /$ artery & $0.03 \pm 0.02$ & $0.27 \pm 0.04$ & 0.11 & $71 \pm 4$ & $<0.01$ \\
\hline DX9065 & $10 \mathrm{mg} / \mathrm{kg}$, s.c. & $0.07 \pm 0.04$ & $0.31 \pm 0.07$ & 0.22 & $43 \pm 6$ & $<0.05$ \\
\hline
\end{tabular}

Values are means $\pm \mathrm{SD}(n=10-12)$. *Mann-Whitney $\mathrm{U}$ test. 


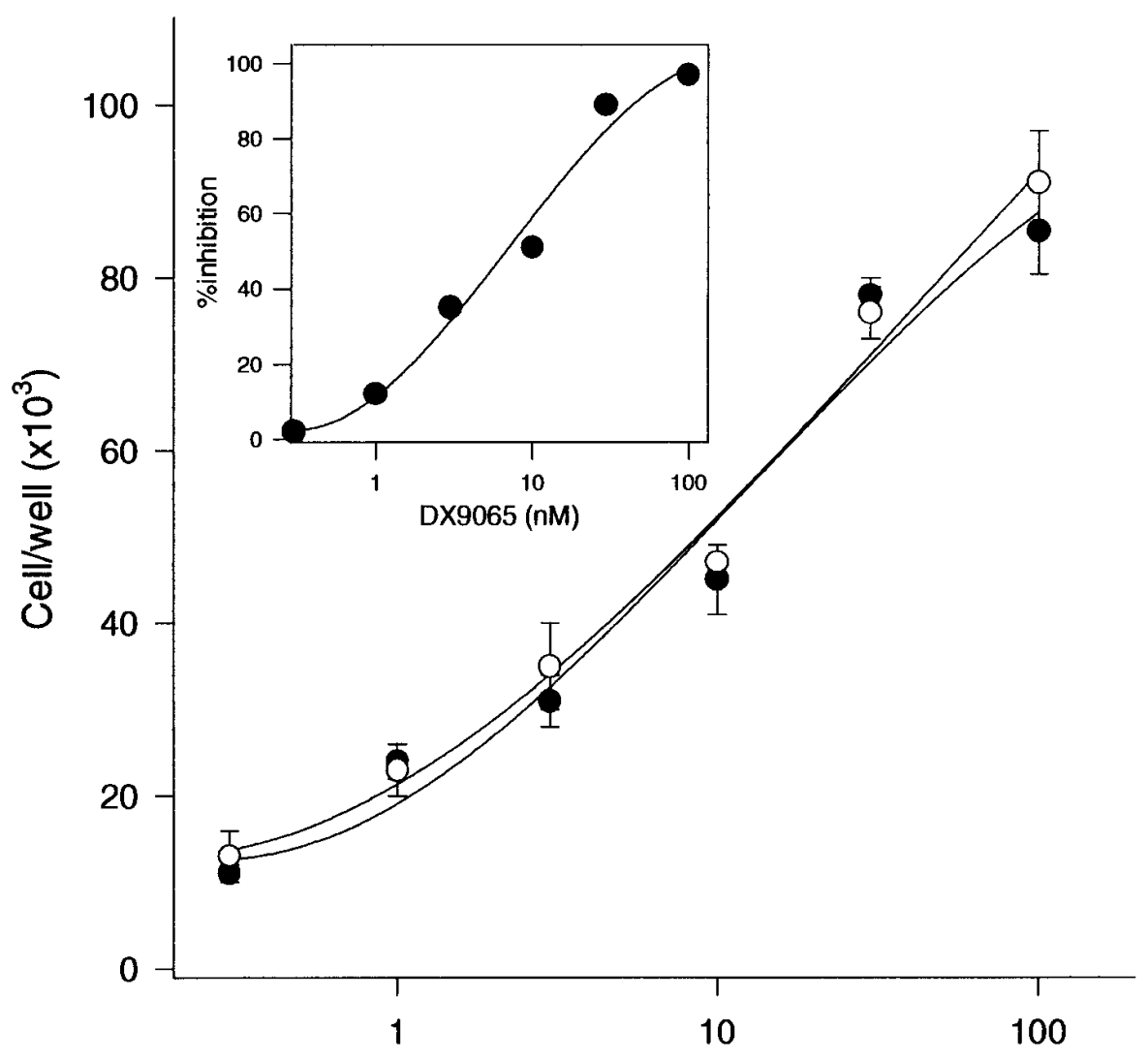

Agonist concentration (nM)
Figure 4. Mitogenic effect of factor Xa for human SMCs. Growth-arrested human SMCs were seeded $\left(10^{4}\right.$ cells/well $)$ in culture medium containing $0.5 \%$ FCS and the indicated concentrations of factor $\mathrm{Xa}(\mathbf{\bullet})$ or thrombin $(\bigcirc)$. After $3 \mathrm{~d}$ in culture, cells were trypsinized and counted. Data are reported as mean cell density $\pm \mathrm{SD}(n=9)$. (Inset) Effect of DX9065 on factor Xa $(100 \mathrm{nM})$-induced SMC proliferation.
$71 \pm 4 \%$ inhibition, respectively; $n=10, P<0.01)$. It is noteworthy that morphological examinations revealed that these antibodies did not change the histological appearance of neointimal cells or extracellular matrix (not shown). The intimal cross sectional area as well as the intima/media ratio were reduced significantly in the injured arteries from animals treated daily with DX9065 (10 mg/kg/d, s.c.). The extent of inhibition of the neointimal formation with this compound was $43 \pm 6 \%$ inhibition $(n=10, P<0.05)$ (Table III).

\section{Discussion}

Assembly of coagulation pathways occurs on vascular endothelial cells through the regulated ligand recognition of membrane protease receptors (14), but besides coagulation, recent studies have also underscored the participation of protease receptors in pleiotropic mechanisms of vascular cell signal transduction of activation-dependent genes (15), generation of intracellular second messengers, and cell proliferation $(1,16-$ 18). Aberrations of protease-dependent signaling pathways may play a primary pathogenic role in the establishment and progression of the atherothrombotic disease (18) as well as in neoplastic transformation and tumor cell dissemination (17, 19). Among the various proteases known to interact with vascular cells, factor Xa has been shown to bind to platelets (20, $21)$, bovine aortic endothelial cells $(5,6,22)$, alveolar macrophages (23), leukocytes $(24,25)$, hepatoma (26), platelets $(20$,
21), HepG2 cells, and bladder carcinoma J82 cells (27), and more recently, HUVECs $(5,6)$ and SMCs $(5)$.

This work shows for the first time the existence of high affinity functional factor $\mathrm{Xa}$ binding sites in human vascular SMCs. It indicates that factor Xa binding to SMC is saturable, time- and calcium-dependent, and is not affected by temperature in a range of $4-37^{\circ} \mathrm{C}$. ${ }^{125} \mathrm{I}$-factor Xa binding on SMCs was inhibited in a competitive manner by factor Xa but not by its precursor factor $\mathrm{X}$, therefore showing that activation of the $\mathrm{zy}$ mogen was required for cell binding. However, since DX9065, a direct factor Xa inhibitor, did not affect ${ }^{125} \mathrm{I}$-factor Xa binding on SMCs, the enzymatic activity of this enzyme seems not to be required for cell binding. Therefore, this observation discriminates factor $\mathrm{Xa}$ from other proteases such as thrombin, for which enzymatic activity is an absolute prerequisite for binding and activity (26). In this regard, the interaction between factor $\mathrm{Xa}$ and surface receptors is also distinct from that reported for bovine aortic endothelial cells $(5,6,22)$. The failure of other homologous proteins, e.g., thrombin, factor VII, or factor $\mathrm{V}$ (not shown), to compete with factor $\mathrm{Xa}$ binding confirms that specificity is restricted to factor Xa.

The binding sites of factor Xa on SMCs are similar to those reported for bovine and human endothelial cells $(5,6,22)$ and for HepG2 and J82 human tumor cell lines (27), and possibly related to that reported earlier on platelets and on a variety of peripheral blood cells, including monocytes (25). Indeed, the possibility that this specific factor Xa receptor is the so-called EPR-1 reported on these latter cells (25) is suggested by the 


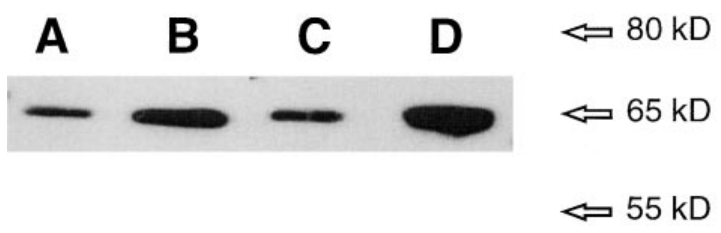

Figure 5. Expression of EPR-1 in SMCs in vitro and in vivo. SMCs cultured for $24 \mathrm{~h}$ in $0.5 \%$ FCS (quiescent) $(A)$ or in $10 \%$ FCS $(B)$, isolated from normal rabbit carotid artery $(C)$ or $14 \mathrm{~d}$ after vascular injury $(D)$ were washed, solubilized in homogenization (lysis) buffer, and centrifuged. Supernatants (500 $\mu \mathrm{g}$ protein/lane) were analyzed in $7 \%$ SDS-PAGE gels. After transfer to Immobilon-P, the membrane was reacted with anti-EPR-1 antibody $12 \mathrm{H} 1$ at $10 \mu \mathrm{g} / \mathrm{ml}$. Samples were visualized using the enhanced chemiluminescence detection kit.

ability of specific mAbs directed against EPR-1 to inhibit binding of ${ }^{125} \mathrm{I}$-factor Xa to SMCs. Consistent with this model, we have found that a peptide representing the interconnecting EGF sequence $\mathrm{Leu}^{83}-\mathrm{Leu}^{88}$ in factor Xa (10) mediates binding to EPR-1 on SMCs. Moreover, competition experiments with the sequence-specific JC15 antibody (which recognizes the $\mathrm{Leu}^{83}$-Leu ${ }^{88}$ sequence) unmasked upon activation of factor $\mathrm{X}$ to factor Xa provide further evidence for activation-dependent conformational changes necessary for factor $\mathrm{Xa}$ to bind to EPR-1 on SMC. Therefore, at variance with the paradigm of protease-activated receptors $(28,29)$ but analogous to the recognition of the urokinase receptor (30), the interaction of factor Xa with the A1 extracellular region of EPR-1 (31) did not require an intact catalytic site in the ligand. Rather, EPR-1 recognition of factor Xa was mediated by the inter-EGF sequence $\mathrm{Leu}^{83}-\mathrm{Leu}^{88}$, which acquired receptor binding specificity in the active protease, but not in the zymogen factor $X(10,32)$. Therefore, although these data identify the inter-EGF sequence in factor Xa as mediating ligand binding to SMCs, additional requirements may be involved in postreceptor occupancy events of factor Xa-dependent signal transduction. In this context, catalytic inactivation of factor Xa abolished EPR1-stimulated phosphoinositide turnover and proliferation of SMCs as already demonstrated by us $(6)^{2}$ and others (5) on HUVECs. Altogether, these data suggest a cooperative model of factor Xa binding to vascular cell EPR-1, potentially involving an initial Gla-dependent contact stabilized by a high-affinity recognition of the EGF sequence $83-88$, and followed by a step of local proteolysis by cell surface-bound factor Xa for downstream signal transduction events and effector responses. In this respect, we suggested recently that factor $\mathrm{Xa}$-induced endothelial-dependent relaxation of rat aortic rings, a novel property of factor Xa, occurred via EPR-1 but also through cleavage of proteinase-activated receptor 2 , the recently described receptor for trypsin, acting as a coreceptor (9). The inability of the thrombin-specific antagonist hirudin to affect factor Xa-induced phosphoinositide turnover and proliferation confirmed the specificity of this pathway, and ruled out a potential participation of downstream activation of coagulation. On the other hand, the ability of EPR-1-factor Xa interaction to enhance prothrombin activation on several vascular and perivascular cell types $(6,10,21)^{2}$ may provide an additional mechanism for factor Xa to play an important role in vivo as an interface between coagulation and other cellular mechanisms such as inflammation (32) or vascular cell proliferation $(1,2,5,6){ }^{2}$

Indeed, previous investigators have shown that factor $\mathrm{Xa}$, like thrombin, is mitogenic for vascular SMCs (1), therefore suggesting that it could play a role in the atherothrombotic process. In this investigation, we confirmed these observations, showing a proliferative response similar to what could be observed for thrombin under the same experimental conditions $(33,34)$.

It is a common feature that the mitogenic effect of proteolytic enzymes (such as thrombin) for vascular cells is due to the autocrine release of growth factors such as bFGF or PDGF by the cells. To determine if such an effect accounted for factor Xa on SMCs, we evaluated the activity of several neutralizing $\mathrm{mAbs}$ with regard to factor $\mathrm{Xa}$-induced SMC proliferation. The inhibitory effect with regard to the proliferative effect of factor $\mathrm{Xa}$ of an $\mathrm{mAb}$ which neutralized the activity of PDGF$\mathrm{BB}$ indicated that the mitogenic activity generated by cultured SMCs in response to factor Xa involved PDGF-like molecules. These results confirm and extend recent data from us (6) and others (2) showing that factor Xa exerts its mitogenic effect indirectly via the release of PDGF that leads to the activation of MAP kinase, DNA synthesis, and growth.

Western immunoblotting experiments demonstrated that mAbs to EPR-1 reacted with an $\sim 65-\mathrm{kD}$ band, entirely consistent with previous results (5). Since the antibody used (12H1) cross-reacted with EPR-1 of rabbit origin (Table II and Fig. 5), we were also able to demonstrate the presence of EPR-1 in the rabbit carotid artery. We have also demonstrated EPR-1 immunostaining of vessels within rabbit tissue, introducing the

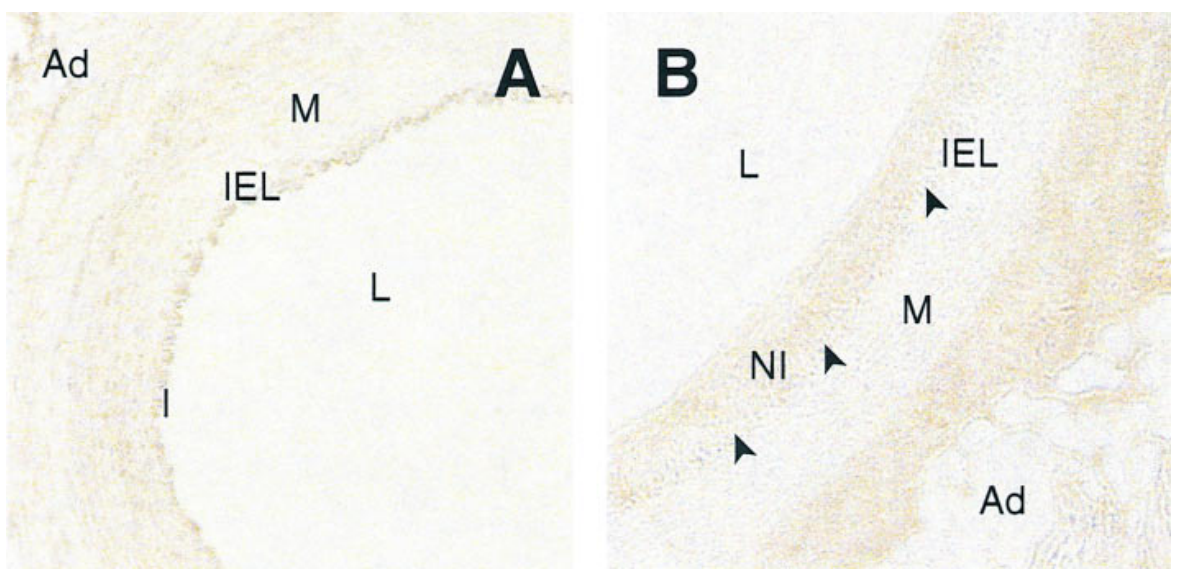

Figure 6. Expression of EPR-1 after vascular injury of the rabbit carotid artery. EPR-1 was detected by immunohistochemistry in normal $(A)$ or air-injured $(B)$ carotid arteries $14 \mathrm{~d}$ after endothelial injury. Immunohistochemical detection of EPR-1 was performed as described in Methods. Arrowheads, Border of residual media and beginning of the neointima. $M$, media. $A d$, adventitia. $L$, Lumen. $N I$, Neointima. IEL, Internal elastic lamina. $I$, Intima. Original magnification $\times 350$. 
potential for EPR-1 to participate in cellular responses directly or in association with local activation of coagulation cascades, which therefore might elicit SMC mitogenesis in vivo. Increased functional expression of EPR-1 was further found in proliferating SMCs and in the neointima of vascular-injured rabbit carotid artery $14 \mathrm{~d}$ after deendothelialization, suggesting that preferential expression of EPR-1 after vascular injury provides a novel activation marker for activated SMCs and highlighting the potential participation of receptor-mediated coagulation and signaling pathways in the histopathogenesis of atherothrombosis. This was further emphasized by our results showing that quantitative histopathology of the rabbit carotid artery $2 \mathrm{wk}$ after the local administration of mAbs directed against EPR-1 (12H1) or against the factor Xa peptide 83-88 (JC15) resulted in significantly less myointimal proliferation compared with controls. Moreover, arteries of animals treated with DX9065, a direct and selective factor Xa inhibitor, had less neointimal proliferation than was observed in controls. These data suggest that EPR-1/factor Xa plays a direct role in restenosis in this animal species. This study complements our previous work in the same animal model using the specific thrombin inhibitor recombinant desulphatohirudin (35), and lends support to the hypothesis that elements of the coagulation system, either through thrombus formation or because of other mitogenic effects, are important in restenosis after vascular injury in this animal model.

Therefore, our results demonstrate the existence of functional factor Xa receptors on SMCs, related to EPR-1, represent the first evidence for the possible importance of EPR-1 in the mitogenic effect of factor Xa for these cells, and raise the interesting possibility of an active role of this factor Xa receptor in several processes where abnormal SMC proliferation has been acknowledged, such as atherogenesis.

\section{Acknowledgments}

We thank Dr. D. Altieri (Yale University School of Medicine, New Haven, CT) for his insightful comments during the preparation of this manuscript.

\section{References}

1. Gasic, G.P., C.P. Arenas, T.B. Gasic, and G.J. Gasic. 1992. Coagulation factors $\mathrm{X}, \mathrm{Xa}$, and protein $\mathrm{S}$ as potent mitogens of cultured aortic smooth cells. Proc. Natl. Acad. Sci. USA. 89:2317-2320.

2. Ko, F.N., Y.C. Yang, S.C. Huang, and J.T. Ou. 1996. Coagulation factor $\mathrm{Xa}$ stimulates platelet-derived growth factor release and mitogenesis in cultured vascular smooth muscle cells of rats. J. Clin. Invest. 98:1493-1501.

3. Ragosta, M., L.W. Gimple, S.D. Gertz, C.T. Dunwiddie, G.P. Vlasuk, E.R. Powers, W.C. Roberts, and I.J. Sarembock. 1994. Specific factor Xa inhibition reduces restenosis after balloon angioplasty of atherosclerotic femoral arteries in rabbits. Circulation. 89:1262-1271.

4. Altieri, D.C., and T.S. Edgington. 1990. Identification of effector cell protease receptor-1: a leukocyte-distributed receptor for the serine protease factor Xa. J. Immunol. 145:246-253.

5. Nicholson, A.C., R.L. Nachman, D.C. Altieri, B.D. Summers, W. Ruf, T.S. Edgington, and D.P. Hajjar. 1996. Effector cell protease receptor-1 is a vascular receptor for coagulation factor Xa. J. Biol. Chem. 271:28407-28413.

6. Bono, F., J.P. Herault, C. Avril, P. Schaeffer, and J.M. Herbert. 1997. Human umbilical vein endothelial cells express high affinity receptors for factor Xa. J. Cell. Physiol. 172:36-43.

7. Hara, T., S. Kunitada, and M. Iwamoto. 1993. DX-9065a, a synthetic and selective factor Xa inhibitor: species difference in its anticoagulant activity. Thromb. Haemost. 69:890-896.

8. Lormeau, J.C., J.P. Hérault, C. Gaich, T. Barzu, T.G. van Dinther, A. Visser, and J.M. Herbert. 1997. Determination of the anti-factor Xa activity of the synthetic pentasaccharide SR 90107A/Org 31540 and of two structural ana- logues. Thromb. Res. 85:67-75.

9. Schaeffer, P., A.M. Mares, F. Dol, F. Bono, and J.M. Herbert. 1997. Coagulation factor $\mathrm{Xa}$ induces endothelium-dependent relaxations in rat aorta. Circ. Res. 81:824-828.

10. Ambrosini, G., J. Plescia, K.C. Chu, K.A. High, and D.C. Altieri. 1997. Activation-dependent exposure of the inter-EGF sequence $\mathrm{Leu}^{83}-\mathrm{Leu}^{88}$ in factor Xa mediates ligand binding to effector cell protease receptor-1. J. Biol. Chem. 272:8340-8345.

11. Munson, P.J., and D. Rodbard. 1980. Ligand: a versatile computerized approach for characterization of ligand-binding systems. Anal. Biochem. 107: 220-239.

12. Berridge, M., C. Dawson, C. Downes, C. Heslop, and R. Irvine. 1983. Changes in the levels of inositol phosphates after agonist-dependent hydrolysis of membrane phosphoinositides. Biochem. J. 212:473-482.

13. Herbert, J.M., A. Tissinier, G. Defreyn, and J.M. Maffrand. 1993. Inhibitory effect of clopidogrel on platelet adhesion and intimal proliferation after arterial injury in rabbits. Arterioscler. Thromb. 13:1171-1179.

14. Davie, E.W., K. Fujikawa, and W. Kisiel. 1991. The coagulation cascade: initiation maintenance and regulation. Biochemistry. 30:10363-10370.

15. Daniel, T.O., V.C. Gibbs, D.F. Milfay, M.R. Garovoy, and L.T. Williams. 1986. Thrombin stimulates c-sis gene expression in microvascular endothelial cells. J. Biol. Chem. 261:9579-9582.

16. Coughlin, S. 1993. Thrombin receptor structure and function. Thromb. Haemostasis. 70:184-187.

17. Stitt, T.N., G. Conn, M. Gore, C. Lai, J. Bruno, J. Fisher, J. Gies, P.F. Jones, T.E. Ryan, D.H. Chen, et al. 1995. The anticoagulation factor protein S and its relative, GAS6, are ligands for the Tyro 3/AXL family of receptor tyrosine kinases. Cell. 80:661-670.

18. Ross, R. 1993. The pathogenesis of atherosclerosis: a perspective for the 1990s. Nature. 362:801-809.

19. Kook, Y.H., J. Adamshi, A. Zelent, and L. Ossowski. 1994. The effect of antisense inhibition of urokinase receptor in human squamous cell carcinoma on malignancy. EMBO (Eur. Mol. Biol. Organ.) J. 13:3983-3991.

20. Tracy, P.B., M.E. Nesheim, and K.G. Mann. 1992. Platelet factor Xa receptor. Methods Enzymol. 215:329-360.

21. Bouchard, B.A., C.S. Catcher, B.R. Thrash, C. Adida, and P.B. Tracy 1997. Effector cell protease receptor-1, a platelet activation-dependent membrane protein, regulates prothrombinase-catalyzed thrombin generation. $J$. Biol. Chem. 272:9244-9251.

22. Rodgers, G.M., and M.A. Shuman. 1985. Characterization of the interaction between factor Xa and bovine aortic endothelial cells. Biochim. Biophys. Acta. 844:320-329.

23. McGee, M.P., and H. Rothberger. 1986. Assembly of the prothrombin activator complex on rabbit alveolar macrophage high-affinity factor Xa receptors. J. Exp. Med. 164:1902-1914.

24. Tracy, P.B., L.L. Eide, and K.G. Mann. 1985. Human prothrombinase complex assembly and function on isolated peripheral blood cell populations. $J$. Biol. Chem. 260:2119-2124.

25. Altieri, D.C. 1995. Xa receptor EPR-1. FASEB (Fed. Am. Soc. Exp. Biol.) J. 9:860-865.

26. Kasama, K., J. Komiyama, and W. Kiesel. 1993. Tissue factor pathway inhibitor and protease nexin-1 are major factor Xa binding proteins on the HepG2 cell surface. Blood. 81:676-682.

27. Sakai, T., and W. Kiesel. 1990. Binding of human factors X and Xa to HepG2 and J82 human tumor cell lines. J. Biol. Chem. 265:9105-9113.

28. Wu, X., M.H. Helfrich, M.A. Horton, L.P. Feigen, and J.B. Lefkowith. 1994. Fibrinogen mediates platelet-polymorphonuclear leukocyte cooperation during immune complex glomerulonephritis in rats. J. Clin. Invest. 94:928-936.

29. Nystedt, S., K. Emilsson, C. Wahlestedt, and J. Sundelin. 1994. Molecular cloning of a potential proteinase-activated receptor. Proc. Natl. Acad. Sci. USA. 91:9208-9212.

30. Appella, E., E.A. Robinson, S.J. Ullrich, M.P. Stoppelli, A. Corti, G. Cassani, and F. Blasi. 1987. The receptor-binding sequence of urokinase: a biological function for the growth-factor module of proteases. J. Biol. Chem. 262: 4437-4440.

31. Ambrosini, G., and D.C. Altieri. 1996. Molecular dissection of effector cell protease receptor-1 recognition of factor Xa. J. Biol. Chem. 271:1243-1248.

32. Cirino, G., C. Cicala, M. Bucci, L. Sorrentino, G. Ambrosini, G. DeDominicis, and D.C. Altieri. 1997. Factor Xa as an interface between coagulation and inflammation. Molecular mimicry of factor Xa association with effector cell protease receptor-1 induces acute inflammation in vivo. J. Clin. Invest. 99:24462451.

33. Herbert, J.M., E. Dupuy, M.C. Laplace, J.M. Zini, R. Bar-Shavit, and G. Tobelem. 1994. Thrombin induces endothelial cell growth via both a proteolytic and a nonproteolytic pathway. Biochem. J. 303:227-231.

34. Herbert, J.M., I. Lamarche, and F. Dol. 1992. Induction of vascular smooth muscle cell growth by selective activation of the thrombin receptor. Effect of heparin. FEBS (Fed. Eur. Biochem. Soc.) Lett. 301:155-158.

35. Herbert, J.M., A.F. Guy, I. Lamarche, A.M. Mares, P. Savi, and F. Dol. 1997. Intimal hyperplasia following vascular injury is not inhibited by an antisense thrombin receptor oligodeoxynucleotide. J. Cell. Physiol. 170:106-114. 